\title{
Are non-traditional security challenges leading regional organizations towards greater convergence?
}

\author{
The EU and ASEAN security systems in comparative \\ perspective
}

\author{
Angela Pennisi di Floristella
}

Received: 15 July 2012 /Revised: 21 September 2012 / Accepted: 16 November 2012 /

Published online: 30 November 2012

(C) Springer-Verlag Berlin Heidelberg 2012

\begin{abstract}
How are regional organizations responding to the emergence of nontraditional security (NTS) challenges? Are they engaging in more cooperative efforts to meet new threats? Or, on the contrary, do they react in different manners according to their distinctive values, principles and internal structures? This article attempts to investigate how the threats posed by NTS are compelling different regional organizations to reconsider their security thinking and to find new innovative ways of cooperation. This is done by comparing two diverse regional organizations, the EU and the Association of Southeast Asian Nations (ASEAN), whose models of security cooperation have significantly varied reflecting the preference for different security approaches. The EU's security system has been more formalized and institutionalized; conversely, the "ASEAN way" has traditionally been rooted in the principles of informality and consensus. It is argued, however, that the emergence of NTS threats is acting as a catalyst behind a normative and operational shift of the modus operandi of both organizations. In so doing, this empirical analysis will try to shed light on the effects of exogenous factors on the emergence of patterns of convergence within the security sphere of distinctive regional processes.
\end{abstract}

\section{Introduction}

The complexity of contemporary security threats has had a significant impact on the agenda of regional institutions. As the contemporary world system has turned into a "world risk society", characterized by "spatial, temporal and territorial de-bounding of uncontrollable risks" (Beck 2002, p. 24), the importance of regional institutions acquired a growing prominence to deal with those threats, which bypass states' functional and political boundaries from "above" and "below", and challenge the

\footnotetext{
A. Pennisi di Floristella ( $\square)$

Dipartimento di Scienze Politiche e Sociali, Università di Catania, via Vittorio Emanuele, 49,

95131 Catania, Italy

e-mail: angipennisif@yahoo.com
} 
functioning and social integrity of societies. In this context, multilateral action has increasingly been deemed as the most effective way to deal with new sources of insecurity arising primarily out from non-military spheres, such as terrorism, piracy, natural disasters and climate change, infectious diseases, organized crime and illegal immigration.

Against this background, the aim of this paper is to investigate the implications of non-traditional security (NTS) threats on regional policy change processes. Do we observe adaptation of distinctive regional organizations to the external environment? Are regional institutions pushing forward new forms of cooperative security? Or, on the contrary, do they react differently according to their inherent principles, values, security cultures and internal structures? To answer these questions, given the sheer diversity of Southeast Asian and European structures and security approaches in terms of content and agenda priorities, set of ideas and norms, a comparative study of ASEAN (Association of Southeast Asian Nations) and the EU modus operandi, in the face of NTS challenges, offers a good lens of analysis to assess the impact of systemic factors on changes of regional security strategies and modalities of security cooperation.

To date, the rise of NTS threats has not escaped the attention of IR students. However, academic debate in European and Asian studies has been devoted to individual regional organizations rather than to global trends. In particular, IR scholarship has put the evolution and performance of regional institutions in the face of new threats under closer scrutiny. For instance, within European studies, Beyer has suggested that the EU can be termed an actor in the security field of counterterrorism (Beyer 2008), Kirchner and Sperling have developed the concept of security governance to capture the engagement of the EU in a complex spectrum of security tasks (Kirchner and Sperling 2007). Other scholars, who have investigated the role of the EU in managing complex transboundary challenges, have suggested that the EU is reshaping its security identity towards a post-national security system (Ekengren et al. 2006; Boin and Ekengren 2009). Similarly, Southeast Asian scholars have explored the dynamics of securitization of NTS issues (Caballero Anthony et al. 2006), and particularly, Caballero Anthony (2008) has drawn attention on the implications of pandemics on the redefinition of ASEAN institutional architecture. With few exceptions, however, only limited effort has been made to shed light on the effects of the systemic context on the agendas of distinct regional institutions. On the contrary, given the idea that it was unlikely there was "anything comparable to the EU in the Asia Pacific" (Jetschke and Murray 2011, p. 175), existent contributions have so far preferred to focus on interregional dynamics (Rees 2010; Murray and Rees 2010).

This article thus attempts to overcome this gap. In particular, it intends to empirically examine how threats posed by NTS are compelling two different regional institutions to rethink their security approaches and to find new innovative ways of cooperation. In so doing, unlike in other studies (Rees 2010), we argue that the assertion that the EU and ASEAN approach to security continues to reflect unique forms, underpinned by the regional context should be relaxed. It is indeed true that ASEAN and the EU betray different security conceptions and forms of cooperation. Notably, in fact, the ASEAN security system has mostly been focused on the prevention of conflicts through its unique approach centred on the commitment to solidarity, informality, minimal institutionalization and non-interference (Acharya 
2009; Amer 2008). Conversely, the EU security approach has come to be known for its more intrusive, institutionalized and formal character, which since the 1990s rendered the EU a significant security actor capable of delivering common security strategies and of developing its own military and civilian capabilities of crisis management, conflict resolution and post-conflict peace building (Beyer 2008; Kirchner and Sperling 2007).

Nevertheless, regional institutions are "dynamic spaces", whose policies do not uniquely derive from agent values, culture, principles and ideas, but follow from the interplay of diverse components, also originating in the external environment. Therefore, it would be misleading to assume linear policy processes, resulting directly from the policy actors' conceptions of security and normative values, because there are systemic conditions and challenges that prevail over an actors' capability to elaborate their strategies. Structural processes pose, in fact, important constraints on the agendas of regional institutions, which react to the changes of the international system by reshaping their political priorities, redesigning their institutional architectures, and advancing new norms and modes of cooperation. Thereby, in line with a structurationist approach, according to which "agency and structures are two sides of the same coin" (Hay 1995, p. 197), we here argue that under the pressure of systemic factors there is a tendency of distinctive regional processes to grow more alike, in terms of increasing similarity of norms and policies.

Taking the ASEAN and EU security systems as two suitable cases to illustrate this trend, our empirical analysis will thus proceed as follows. The article will first take a look at EU and ASEAN traditional security models and approaches. Then, the focus will address the concurrent normative evolution of EU and ASEAN security concepts and strategies, in reaction to the emergence of NTS threats. Finally, through the prism of two case studies on terrorism and disaster management, we will attempt to trace the ASEAN and EU shift towards forms of cooperative security in the face of NTS threats. In particular, the ASEAN and the EU response is analysed focusing on the processes of adaptation and recalibration of institutional norms, structures and activities.

\section{Two different security approaches: the EU and ASEAN systems in comparative perspective}

European and Southeast Asian security approaches have traditionally been very different stemming from disparities in their institutional form, type of identity and internal structure as well as diverse understandings, interests and goals underlying processes of security cooperation (Katzenstein 2005). Asymmetries in modalities of cooperation, security strategies and degree of institutionalization follow distinctive regional contexts, and strategic cultures.

In particular, with the dissolution of the Soviet Union and the outbreak of the war in the Balkans, the EU developed a more autonomous security policy thus moving away from its traditional normative, value-driven external policy, which justified the label of "normative power Europe" (Manners 2002), to broaden its capabilities beyond the civilian sphere. The first step in this direction has been the Treaty of Maastricht, which "permitted to address the previously taboo question of defence" 
(Bindi 2010, p. 27). Since then, thanks also to a greater degree of historical, political and economic homogeneity European integration has progressed both vertically and horizontally and has thus developed new supranational institutions. In particular, in the security sphere member states have launched several military and civilian initiatives, among others, the EU's Petersberg tasks (1997) and Headline Goals (1999). Under these auspices, the European Defence and Security Policy (ESDP) came into existence to facilitate the development of a European capacity in conflict management, and from 1999, institutional structures aimed at equipping the EU with new capabilities have been introduced. Additionally, a series of targets for increasing deployable assets have been added to the civilian component of the ESDP (Duke and Ojanen 2006; Bindi 2010). In 2004, a European Defence Agency was established to support European policy in crisis management, and in 2005 the Battle Group Capability was activated to conduct short-term missions. The other institutional changes inaugurated with the Lisbon Treaties have further consolidated the role of the Union in the attempt to render its external policies more coherent.

Certainly, one cannot ignore the fact that European security and defence policy remains handicapped by its intergovernmental nature, which continues to form a fundamental barrier to deeper integration and undermines the European capacity to speak with a single voice on various sets of security issues. Nevertheless, the growing security profile and high institutional density of the EU has been shown by greater capability of conducting and planning autonomous missions, as well as using as assets of soft diplomatic engagement, and also military means, depending on the background scenario of the conflict and by cooperating effectively with the UN and other international bodies to halt international and domestic violence and accomplish particularly significant assignments.

Compared to the EU, the so-called "ASEAN way" of managing disputes was clearly outside the parameters of formal structures and institutions (Caballero Anthony 1998), and sharply contrasted with a Western legalistic criterion of cooperation. ASEAN has claimed a unique modus operandi in terms of the decision-making process and approach to institutionalization, which very much reflects a distinctive security culture rooted in the practice of consultation (musyawarah), and in the search for consensus building (mukafat) typical of Javanese village societies (Acharya 1999). ASEAN thus came to be recognized for its preference for a flexible modus operandi, and for the practice of socialization based on cautious diplomacy, personal ties and informal style. This institutional design also reflects the historical circumstances of the region where, because of the need to consolidate the independence of post-colonial states, and to preserve national sovereignty against external influences, ASEAN elites opted for loose modes of cooperative security and non-interference. Of no less significance, the differences among ASEAN members in terms of political and governmental systems, levels of economic development, religious and cultural traditions, very much explain resistance to any pooling of sovereignty and to the adoption of binding instruments of crises management. Unsurprisingly therefore, the only attempt to provide the Association with a formal mechanism of conflict management can be found in the TAC, whose norms nonetheless demonstrate the choice for a "light institutional framework", resulting from the member states' commitment to solidarity, informality, minimal institutionalization, non-interference, respect for 
national sovereignty and peaceful settlement of disputes and cooperation (Acharya 2009; Amer 2008; Narine 2008).

This security model continued to govern inter-state cooperation in Southeast Asia up until the end of the Cold War, although the more relaxed competition for power, and the ascendancy of the democratization process in the five ASEAN countries (Indonesia, Malaysia, Thailand, Philippines and Singapore) opened a new window of opportunities for ASEAN to redefine its regional role, and to get involved in new frameworks of cooperative arrangements, culminating in the ASEAN Regional Forum (ARF). Nevertheless, due to their everlasting ethnic, political, economic and territorial tensions ASEAN members remained reluctant to cede to the Association a portion of their sovereign prerogatives in the security sphere. Not surprisingly therefore, even Surin Pitsuwan's proposal for a policy of "flexible engagement" was rejected because of the fear of any potential violation of the principle of non-interference.

In summation, while in the course of the 1990s, through a unique combination of civilian and military components the EU was evolving into a sophisticated framework of security cooperation, the Association was neither putting into place formal mechanisms of operational prevention to address immediate crises, nor forceful measures to deal with them. On the contrary, its members remained strongly attached to the core values of the "ASEAN way" and resisted any allocation of competence to a supranational organization.

\section{Rethinking security under NTS}

If ASEAN and the EU have conceptualized security and set the content and priorities of their agendas according to their own distinctive values and regional contexts, in recent years the emergence of NTS threats signifies a fundamental shift away from their unique modus operandi. New turbulence on the periphery of the EU increasingly exposed the region to waves of refugees and disruption of trade (Biscop 2005). Failed states and military conflicts in Central Asia, the Balkans and Northern Africa became the transmission belt of illegal immigration, transnational crime and crime-related activities. Terrorist attacks in Madrid (2004), and London (2005), linked to violent religious fundamentalism, put the safety and openness of the EU societies at risk. In parallel, the 1997 financial crisis, the 2002 and 2005 Bali bombings, natural calamities, the epidemic of Severe Acute Respiratory Syndrome (SARS), the presence of terrorist groups, such as Jemah Islamiah (JI), the Moro Islamic Liberation Front (MILF) and Abu Sayyaf Group (ASG), and transnational crime and illegal trafficking, have detrimentally affected the security and well-being of ASEAN states and have severely exacerbated interstate relations.

The nature of NTS threats, which is "short of the traditional state-versus-state pattern" (Maier-Knapp 2010, p. 78) gave a strong impetus for a redefinition of security concepts. The growing realisation that "a range of new referent objects and threats is being set up above, below and alongside the state" (Buzan 1997, p. 11), compounded with the incapability of national actors to regulate the "entry" and "exit" of these issues, and contain their effects put the issue of coordination into sharp relief, which opened the path for a novel role of regional organizations, to overcome 
problems of collective action. These systemic conditions prevailed over the ability of regional institutions to elaborate new security strategies and implement new operational instruments aimed at putting into place concerted mechanisms for the comanagement of their mutual sources of insecurity. As a result, the EU and ASEAN both embarked on a wide array of initiatives aimed at recalibrating and adapting their security systems to the contemporary external environment. No wonder therefore that while, on one hand, traditional security conceptions linked to territorial integrity, political independence and the sovereignty of states gradually started to loose ground, on the other hand, cooperative and comprehensive security approaches began to emerge as the predominant facets of contemporary security discourses.

\section{A new European security approach}

As correctly pointed out by Biscop and Coolsaet, while during the Cold War European security was essentially conceived in military terms as the avoidance of a military danger against a clearly identified foe, in the absence of a major military threat, other factors that can intrinsically affect the values and interests of the EU, have come much more to the fore such as organised crime, illegal immigration, social and economic underdevelopment, lack of democratic institutions and respect for human rights, failed States, dysfunctional multilateral institutions and ecological problems (Biscop and Coolsaet 2003). This new security environment has been the starting point for the report Secure Europe in a Better World - European Security Strategy (ESS), released by the EU High Representative for the CFSP, Javier Solana, in 2003. The document responds to the need to adapt European norms to "more diverse, less visible and unpredictable" threats that "no single country is able to tackle entirely on its own". In so doing, the ESS takes a step beyond traditional state-centric conceptions, and in recognition of the new security landscape, and of the growing nexus between external and internal security, acknowledging the multidimensional, comprehensive and inclusive character of "security" (Duke and Ojanen 2006; Biscop 2005; Moschini 2008). Terrorism, proliferation of weapons of mass destruction, failed states and organized crime are mentioned as the most important direct threats affecting European security. And significantly, tackling these threats through more appropriate multidisciplinary strategies based on a balanced selection and integration of preventive engagement and military and civilian assets, has become one of the new "strategic objectives" of the EU, listed besides the goals of "extending the zone of security around Europe" and "strengthening the international order through multilateral cooperation".

This new content of European security has then been consolidated by the 2008 Updated Report of the strategy, Providing Security in a Changing World. Importantly, the report gives substance to NTS issues by enlarging the list of security threats to cyber security, energy security, climate change, piracy and small arms, light weapons and cluster munitions. Not less significantly, it calls for EU responsibility in responding to these threats by restructuring its mechanisms, improving institutional coordination, building appropriate and effective command structures and headquarters, developing more strategic decision-making, and addressing the root causes of instability through a "coherent use of political, diplomatic, development, humanitarian, 
crisis response, economic and trade cooperation and civilian and military crisis management".

Taken together, the two documents reflect the process of adaptation of the EU, to the emerging systemic changes deriving from NTS sources, seriously affecting European societies. The new European security notion appears, in fact, to be the result of the interaction between EU's institutions, and threats and vulnerabilities raised by the external system. This EU security concept has thus been redefined by identifying new security priorities and cooperation areas with other global and regional actors. Furthermore, a new path of action into the sphere of internal security has been set forth. This is also evident in the Draft Internal Security Strategy for the European Union: Towards a European Security Model, adopted by the European Council in February 2010, which is the most concrete suggestion for the attempt to elaborate multilateral platforms and strategies of cooperation, in areas which were traditionally left to the domain of national states, it also provides a number of guidelines for action to guarantee EU internal security, with the ultimate goal to creating a common European security model, founded on shared principles, strategies and mechanisms of cooperation, as well as stronger linkages and connections between national and regional capabilities.

\section{ASEAN and the principle of comprehensive security}

Unlike in the EU, the concept of comprehensive security was not novel in Southeast Asia. Already in 1967, the Declaration of Bangkok remarked on the interdependence between economic growth, social progress, cultural development and the promotion of regional peace and stability. And importantly, under the influence of Japan, which in the early 1970 s started to advocate the idea that security cannot be restricted only to military issues, Malaysia, Indonesia and Singapore introduced principles of comprehensive security in their national legislations (Banerjee 1999; Emmers 2009). Remarkably, the concept had good fortune in Indonesia under the leadership of Suharto, who pioneered the doctrine of national resilience (Ketahanan National) postulating "the strengthening of all the component elements in the development of a nation in its entirety, thus consisting of resilience in the ideological, political, economic, social, cultural and military fields" (Suharto 1975 quoted by Emmers 2009, p. 161). ${ }^{1}$

This vision of security was, nonetheless, only confined to national legislations with the consequence that NTS concerns have been primarily seen as domestic problems, dependent upon national solutions and responses (Sukma 2010). This may be explained by the strong state-centric approaches of Southeast Asian security concepts, underpinned by the need to preserve and consolidate the territorial integrity and political independence of the weak post-colonial states, reduce the regional influence of external actors (as stated in the Zone of Peace Freedom and Neutrality of 1971), and avoid a potential domino effect of communist insurgencies. Only recently, after the 1997 financial crisis which spread quickly from Thailand, to

\footnotetext{
${ }^{1}$ In Indonesia, the principle of national resilience drew attention to the issue of domestic development, deemed to be the privileged vehicle to assure regional security. A regional version of the principle of national resilience was then transferred to ASEAN.
} 
Malaysia and Singapore, and in the wake of terrorist attacks ASEAN members realized the necessity of intensifying interstate cooperation by developing collaborative security efforts (Sukma 2010).

Against the backdrop of these events during the ASEAN Bali Concord II, the ASEAN Political Security Community (APSC) came into existence to bring the level of security cooperation to a "higher plane" and improve ASEAN capacities and effectiveness. Notably, ASEAN, "taking into account the strong interconnections among political, economic and social realities, subscribes to the principle of comprehensive security as having broad political, economic, social and cultural aspects in consonance with the ASEAN Vision 2020" (point 2), and its members recognize that cooperation is needed to handle: "concerns that are transboundary in nature, and therefore shall be addressed regionally in holistic, integrated and comprehensive manner" (point 5). Additionally, the APSC attempts to strengthen both its national and regional capacities by fully utilizing "the existing institutions and mechanisms within ASEAN with a view to strengthening national and regional capacities to counterterrorism, drug trafficking, trafficking in persons and other transnational crimes..." (point 10).

This principle of comprehensive security is then re-iterated by the ASEAN Charter, which serves as a firm foundation in achieving the ASEAN Community, by providing ASEAN with a legal status, new powers, and an institutional framework. Undoubtedly, this new conceptualisation of security, which lay at the basis of contemporary ASEAN security documents, underlines an important shift from the dominant security discourse "characterized by the perception of the state as the primary security referent" (Caballero Anthony 2010, pp. 6-7). To this goal, the APSC Blueprint has then provided ASEAN with a roadmap and timetable for the realisation of the ASEAN Community, by identifying specific policy actions aimed at strengthening cooperation in addressing NTS issues, intensifying counterterrorism efforts, strengthening ASEAN Cooperation on Disaster Management and Emergency Response and pushing forward an effective and timely response to urgent issues, or crisis situations affecting ASEAN (ASEAN Political Security Blueprint 2009, pp. 12-14).

Remarkably, these provisions and initiatives are significantly different from ASEAN's usual processes (Caballero Anthony 2010). Most of them are, in fact, "problem solving measures and involve more coordinated responses, among other things the sharing of information, the development of certain types of regional surveillance systems for early warning on infectious diseases and natural disasters, the provision of relief and assistance in disaster management, rehabilitation and reconstruction, and even more significantly, working towards more coordinated responses and making attempts at harmonising legal frameworks in order to address transnational crimes" (Caballero Anthony 2010, p. 7). Therefore, in a manner similar to the European case, the ASEAN security approach not only welcomes a multidimensional view of security, but is also rapidly evolving into the sphere of internal security. Yet, unlike the EU which has traditionally not insisted on respect for the principle of non-interference, this concept is still considered to be one of the pillars of the Southeast Asian security system. It would therefore, be premature to expect a full implementation of the principle of comprehensive security in the Southeast Asian context. Nevertheless, it cannot be neglected to note that under certain circumstances, 
particularly those which are referred to as NTS threats, non-interference is increasingly interpreted in a more flexible way.

\section{Institutional innovations in the arena of NTS: a focus on counter terrorism and disaster management}

After having explored the evolution of the EU and ASEAN security approaches, the second part of this study will outline how these institutions are adapting their norms and operational instruments to address NTS crisis scenarios. The case studies on terrorism and disaster management have been selected for the following reasons to illustrate this trend. First, terrorism and disasters have posed acute problems for both the EU and ASEAN and have demonstrated the need for major coordination. Second, they somehow represent two extremes of security threats. Indeed, while cooperation on terrorism is often complicated by mutual suspicions and insistence on retaining individual sovereignty, disaster management is a less sensitive issue than national sovereignty, and offers greater prospects of successful joint efforts. Thus, by comparing how ASEAN and the EU respond to these sources of insecurity we can get important insights into the influence of exogenous factors in readdressing security policies, even in diverse regional contexts.

\section{The EU and counterterrorism}

At the European level the issue of terrorism has been brought to the top of the regional security agenda in the course of the last decade. Although already in the 1970s TREVI came into existence as a first attempt at cross-border coordination and information exchange, European states could hardly cooperate due to the lack of a common definition of a terrorist threat. The Treaty of Amsterdam, which extended the European scope to internal security, has not overcome this gap with the result that counterterrorism policies remained mostly in the hands of national governments (Beyer 2008).

Pursuant to the 9/11 attack, terrorism became a real threat to Europe. The EU then acted at all levels to adopt normative and operational instruments for cooperation. The Framework Decision on Combating Terrorism (2002) first provided the EU with "a minimum definition of terrorist acts and maximum custodial penalties, indispensable for the comprehensive criminalization and prosecution of terrorist offences throughout the Union" (Monar 2007, p. 305). Soon after, the ESS defined terrorism as a "key security threat", which is often linked to other sources of insecurity, such as money laundering and transnational crime. The Hague Programme (2004) and the Anti-terrorism Action Plan then outlined a number of measures to enhance information and intelligence exchange, and improve cooperation in law enforcement and between police authorities.

The necessity of tackling terrorism through joint actions and efforts then evolved rapidly after the Madrid and London bombings (in March 2004 and July 2005, respectively) and the terrorist attacks which shocked Arab countries (e.g., Casablanca in May, 2003 and Amman in 2005). In 2005, the European Counterterrorism Strategy 
was adopted to provide a holistic and concerted framework of cooperation from intelligence sharing, to law enforcement and control of financial assets. Under the Strategy a comprehensive program covering the areas of prevention, protection, pursuit and response was set up. Specific measures, such as the Strategy for Combating Radicalisation and Recruitment into Terrorism (2005) have been developed to tackle the root causes of terrorism. Furthermore, military and civilian operations conducted under the ESDP, together with external relations policies have served to promote good governance, human rights, democracy, the rule of law, education, economic prosperity and conflict resolution. Economic agreements have also been used to assist countries in combating radicalisation. In addition to this, measures have been introduced to protect European borders and reduce the vulnerability of a terrorist attack. Amongst others these are the Regulation on standards of security and biometrics in passports and travel documents in EU passports (2009), the establishment of the FRONTEX agency (2005), the modernization of the Community Custom Code (2005), a regulation of the VISA information system (2009), a directive establishing a procedure for the identification and designation of European Critical Infrastructure (2008), and measures on the security of explosives. Other initiatives have also been undertaken to impede the planning of terrorist attacks, to cut off their funding and bring terrorists to justice.

Of no less importance, common structures have been established to facilitate regional cooperation such as: the Joint Situation Centre, the EU Arrest Warrant, Europol, Eurojust and the European Police College; and norms, such as the Third Money Laundering Directive (2005), the Regulation on cash couriers (2005), and the Regulation on funds transfers (2006) have been enacted to freeze terrorist assets. Finally, the fulcrum of the EU response strategy are the Mechanism of Civil Protection (MCP) and the related Civil Protection Financial Instrument, which both aim at improving the preparedness of the member states to manage the consequences of a terrorist act.

This overview of European activities provides substance to the assumption that European security policies are directly influenced by NTS challenges. Indeed, the terrorist threat gave a strong boost to the adoption of concrete normative and operational innovations, which significantly reshaped the European security profile. Yet it remains to be seen if the various limits affecting European anti-terrorism policies such as the persistent divide between the threat perception of EU states, the differences of police and judicial traditions, the willingness of national states to maintain their sovereign prerogatives and the cross-pillar structure of the EU counterterrorism policy, can hamper the successful implementation of EU initiatives in the long term.

\section{ASEAN and counterterrorism}

Similarly, as in the European case despite the fact that the ASEAN Ministerial Meeting on Transnational Crime (AMMTC) was being established, as a core ASEAN body on counterterrorism and transnational crime already in the mid-1990s, the ASEAN commitment in the fight against terrorism was initiated after 11 September 2001. The fear that the Al Qaeda terrorist network was setting up local cells, 
particularly in Kuala Lumpur and Bangkok to exploit the regional loose border and financial controls, and cooperate with indigenous regional terrorist groups such as JI, MILF and ASG (Vaughn et al. 2009) led the Bush Presidency to declare Southeast Asia as the "second front" in the fight against terrorism. Against this background ASEAN issued a Declaration on Joint Action to Counter Terrorism (2001), whose measures have been incorporated in the Terrorist Component of the Work Programme to implement the ASEAN Plan of Action to combat Transnational Crime (2002).

A new phase in the fight against terrorism was then inaugurated after the Bali bombings of 2002, which brutally killed approximately 200 people and injured some 200 more, and the series of attacks of 2005. Indonesia had, indeed, to accept the existence within its borders of radical elements pursuing a pan-Islamic project, and became more willing to undertake forms of multilateral initiatives. The negative externalities of the bombings, which were reflected "on a $38 \%$ fall of tourism arrivals in Indonesia, a rise to 3,5 million by 2008 in the number of displaced persons (victims of counter insurgency and of the war) and an average reduction of GDP by $3 \%$ " (Banlaloi 2009, pp. 67-72) all exacerbated the need to overcome unilateral policies in favour of more coordinated approaches to combat the terrorist threat. Not surprisingly therefore, ASEAN leaders not only reiterated their commitment to the fight against terrorism in a new Declaration, but also expressed the desire to accept the UN Conventions to fight terrorism (such as the 1999 International Convention for the Suppression of the Financing of Terrorism) and the willingness to establish a regional cooperation Center in Kuala Lumpur in order to raise the level of cooperation, coordination and information sharing. In this context, several cooperative efforts have been advanced. Amongst others: the adoption of the Agreement on Information Exchange and Establishment of Communication Procedures of $2002,{ }^{2}$ the putting into place of common training programmes and projects to counter terrorism and the adoption of the Vientiane Action Programme 2004-2010, which announced an ASEAN Mutual Legal Assistance Agreement, an ASEAN Convention on Counter Terrorism (ACCT), and the establishment of an ASEAN Extradition Treaty, as envisaged by the 1976 Declaration of ASEAN Concord.

Significantly, the ACCT was adopted during the ASEAN Summit in January 2007, to provide a common framework to enhance the region's counterterrorism capacity and to deepen the level of interstate cooperation. In May 2011, after the deposit of the 6th ASEAN member ratification instrument, the ACCT finally came into force, paving the way for the harmonization of national counterterrorism laws, and the realization of a consistent regional policy on this issue. Thus by arriving at a common "understanding" of terrorism, according to 13 listed UN Treaties (art. 2), the ACCT should facilitate ASEAN joint actions to counter, prevent and suppress terrorist activities. Of no less significance, the Convention creates the first legally binding instrument, valid for all ASEAN countries. One can therefore expect that by making this mechanism more forcible regional cooperation can be strongly enhanced.

\footnotetext{
$\overline{2}$ The Agreement on Information Exchange and Establishment of Communication Procedures of 2002 obliges the parties to cooperate among themselves in preventing the utilization by anyone of their land-airsea territories for the purpose of committing terrorism or other transnational criminal activities (money laundering, smuggling, piracy etc.).
} 
Undoubtedly unlike the EU, ASEAN does not have comparable operational capabilities and efforts to address the terrorist threat have mostly been conducted on an ad hoc basis, through bilateral/trilateral initiatives or alternatively between ASEAN states and ASEAN outside partners, above all the US (Singh and Acharya 2009). This is, however, not surprising given the peculiarity of Southeast Asian security culture and values centred on a kind of "bottom up approach". This particular attitude clearly reflects the interaction existing on one hand, between the domestic dimension of the institution whose values are centred on the principles of informality and non-interference, and on the other hand, the systemic pressures, which are leading ASEAN towards processes of adaptation in the face of the contemporary terrorist threat. In fact, under the pressure of external constraints ASEAN's traditional role of providing the venue, where all parties can meet and discuss at bilateral and trilateral levels, attempting to reduce mutual suspicions and improve the regional climate, making it suitable to cooperation, appears increasingly to be flanked by novel regional efforts oriented at building a system of regional governance capable of managing NTS.

\section{The EU and disaster management}

With regard to disaster management at the EU level initial efforts to assist the needs of the affected member states, such as the Resolution of the Council (1991) aimed at improving aid in cases of technological disasters, and the first Community Action Programme (1999), in the field of civil protection, can hardly be considered effective mechanisms to address major disasters. The drive for effective multilateralism in the area of disaster management arises only after the advent of major calamities such as the earthquake in Turkey (1999) and the Indian Ocean tsunami (2004) (Åhman and Nilson 2009; Boin and Rhinard 2008; Ekengren 2008). Since then, EU member states have been very active in creating institutional structures to promote forms of regional governance. In 2001, the MCP was created to facilitate cooperation in civil protection assistance in the events of major emergencies, which may require urgent response actions on request of the affected country. The added value of the Mechanism was "to oblige the member states to offer a certain level of cooperation, for instance to warn other member states of possible disasters having a cross-border impact" (Åhman and Nilson 2009, p. 86).

Additionally, under the MCP a number of tools were created to facilitate adequate preparedness and effective response. The Monitoring Information Centre (MIC), which is the operational heart of the MCP, was set up to provide a nonstop communication hub between participant states, affected states and dispatched field experts, and to deliver useful and updates information on the ongoing emergency. The Common Emergency and Information System (CECIS) was created to facilitate emergency communication among the participant states. A Training Programme was established to improve the coordination of civil protection assistance and ameliorate the compatibility and complementary strengths of the diverse teams. Civil Protection Modules were also added to the civil protection rapid response capability.

Other relevant proposals for improving the system were then advanced in the aftermath of the Indian Ocean tsunami. Indeed, considering that national states are ill 
equipped to deal with these sources of insecurity European states realized the need to develop a more robust European civil protection capacity, enabling the Union to react more rapidly and effectively to any type of disaster. To this scope, the EU has worked on improving its civil protection actions to be prepared for any disaster that may occur. The adoption of the Rapid Response and Preparedness Instrument for major emergencies $(2005)^{3}$ and the Commission proposal for an instrument enabling the EU to directly provide funds for emergency assistance are the two major steps that have been taken to strengthen EU regional capacity in disaster management. Remarkably, by creating the Civil Protection Financial Instrument (2007) the MCP now possesses resources to cover activities of prevention, preparedness and response. For instance, under the EU's 2007-2013 financial frameworks these funds amount to €189.8 million of which $€ 20$ million are available for actions within the EU and $€ 8$ million for actions in third countries.

Aside from these efforts, the European response also contributes to interventions led by other international organizations. For instance the MIC cooperated with the Commission's own humanitarian Aid Department (ECHO) as well as with the United Nations Office for Coordination of Humanitarian Affairs (OCHA), which coordinated international relief efforts. The recent interventions of the Community Mechanism on the regional and global stage ${ }^{4}$ demonstrate that the EU is redefining its role by taking up new responsibility to provide the most effective assistance in cases of major emergencies.

\section{ASEAN and disaster management}

In the Southeast Asian region, it is difficult to ignore the pressure coming from floods, earthquakes and droughts in terms of losses of people and widespread economic damage. These phenomena have resulted in large-scale emigration and mass movements of refugees, which have also triggered tensions among ASEAN members, and also with other neighbouring states, particularly India and China. Inevitably, disaster management has thus become one of the key areas of ASEAN regional cooperation.

In truth, the ambition to improve mutual assistance for natural disasters was already stated with the adoption, in 1976, of the first ASEAN Declaration on Mutual Assistance on Natural Disasters, which was mostly aimed at improving communication channels, and exchanging information and data pertaining to natural disasters. Despite its importance, the Declaration remained, however, only a declaratory document, and has not achieved significant follow-up.

\footnotetext{
3 This proposal provided the future legal framework for the financing of civil protection operations.

${ }^{4}$ The Community mechanism has now been called up to intervene in a number of major disasters around the globe. These include the floods in Central Europe $(2002,2005,2006)$ and France (2003); the Prestige accident (2002); the earthquakes in Algeria (2003), Iran (2003), Morocco (2004), Pakistan (2005), Indonesia (2006), and Peru (2007); forest fires in France (2003), Portugal (2004, 2005), Spain (2006), and Greece (2007); a major storm in Sweden and snowstorms in Albania (2004); the southeast Asian tsunami 2004; in the aftermath of the Hurricane Katrina in the US (2005); the Lebanon/Cyprus evacuee crisis and oil pollution in Lebanon (2006) and the floods in Bolivia (2007).
} 
Disaster management started to dominate the ASEAN security agenda only after recent dramatic catastrophes: the Indian Ocean Tsunami (2004), Typhoons Xangsane (2006), Ketsana (2009), and Cyclone Nargis in Burma (2008), which became serious problems, both in terms of humanitarian challenges and in terms of security risk. Following these calamities, ASEAN advanced important institutional innovations. In 2003, the ASEAN Committee on Disaster Management (ACDM) was established to assume responsibility for coordinating and implementing all regional activities within this field. The activity of the newly conceived ACDM was then accelerated by the events of the 2004 tsunami, and already in May 2004 the Regional Programme on Disaster Management (ARPDM) was launched to provide a framework of concerted regional cooperation for the period 2004-2010. The programme has defined the regional strategy on disaster management prevention, its priority areas and activities. Furthermore, it has provided a platform for cooperation and collaboration with ASEAN Dialogue Partners and international organizations such as the United States Department of Agriculture Forest Service, the Pacific Disaster Centre, OCHA, UNHCR, UNICEF, IFRC, and Asian Disaster Preparedness Centre (ADPC).

One of the priority projects under the ARDPM was the establishment of an ASEAN Regional Disaster Management Framework to develop an agreement on disaster emergency response, procedures to operazionalize the disaster response mechanism and to enhance a quick response team of Member countries, as well as to conduct simulation exercises. Significantly already in 2005, ASEAN members agreed on the ASEAN Agreement on Disaster Management and Emergency Response (AADMER), which laid down the necessary normative basis for activities within this field. Under this framework which came into force on 24 December 2009, ASEAN members committed themselves to take a more proactive stance to "respond to disaster emergencies through concerted national efforts and intensified regional and international cooperation" (art 2. AADMER). And to this end, a number of actions have been identified.

The Agreement also established an ASEAN Coordinating Centre for Humanitarian Assistance on Disaster Management (AHA Center) charged with coordinating emergency responses offered by ASEAN parties in cases of disasters, and set shared objectives to strengthen national capacities, and foster regional projects to ameliorate ASEAN capacity, improving risk identification and monitoring. The AADMER has also required the preparation of a Standard Operating Procedure, adopted in March 2008. The latter has provided a guide to initiate the establishment of the ASEAN Standby Arrangement for Disaster Relief and Emergency (SASOP); the procedures for joint disaster relief and emergency response operations; the procedures for the facilitation and utilisation of military and civilian assets and capacities, and the methodology for the periodic conduct of the ASEAN regional emergency response simulation exercises (ARDEX) to enhance member countries capabilities in joint disaster relief and emergency responses.

The way in which ASEAN members defined precise targets and measures to adopt illustrates that, contrary to other policies, cooperation within disaster management is more cooperative rather than competitive. The case of Cyclone Nargis, which confronted ASEAN with the opportunity to put into place the mechanisms set down under the AADMER also showed ASEAN increasing its capacity to put into place a collective response to a major disaster to provide for the internal security of its 
community. The mechanisms and tools under the AADMER were indeed, tested and used in a real situation.

\section{Conclusion}

Since the last decade, the international security environment has become more unstable and traditional military security has gradually been supplanted by new forms of threats that are short of the state versus state pattern (Maier-Knapp 2010). Regional institutions have thus been called to redesign their roles and functions within the sphere of NTS. The above discussion has shown that the two regional institutions considered here, namely the EU and ASEAN, in spite of their differences in terms of values, approaches and forms of cooperation, both undertook initiatives aimed at recalibrating and adapting their security systems and models of cooperation to face contemporary problems.

Recognizing the interdependent nature of security and the pressure of similar security threats, the EU and ASEAN started to work hard to elaborate new security strategies. Normative innovations have been displayed in the shift of their security thinking. At the EU level, the adoption of the ESS embodies a new security concept resting on the acknowledgement of the multidimensional, comprehensive and inclusive character of security. Similarly, in the ASEAN context the APSC and the ASEAN Charter have highlighted that a number of political, economic, environmental, and social factors can severely affect the security of societies and individuals within their states. In addition to this, in the course of the last decade, ASEAN and the EU have promoted regional frameworks to handle security matters. As we have seen, terrorist attacks generated a set of new measures regarding internal security aimed at harmonizing perceptions of terrorist norms and increasing intelligence cooperation (Beyer 2008), and new management capacities to respond to natural and man-made disasters have been adopted in the aftermath of recent violent disasters (Maier-Knapp 2010; Caballero Anthony 2010; Guilloux 2009; Ekengren et al. 2006).

Yet, our analysis has shown that the EU has developed a much more sophisticated framework of cooperation, particularly in counterterrorism. The EU can, in fact, claim advanced instruments of legal and judicial cooperation valid throughout Europe, and it also owns instruments of control of external borders, although their effectiveness is being hampered by sovereignty prerogatives and differences in police, judicial and administrative traditions of EU members. Conversely, the Association lacks similar instruments, and its operational capability is rather underdeveloped. Major factors can account for this, for example, the limited resources of the Association, the diversity of the political systems of its members and their traditional reluctance to go beyond noninterference. Nonetheless, the enforcement of the ACCT, which harmonizes a legal framework of cooperation against terrorism and for the first time, provides the region with a legally binding document for all its members, displays on one hand, that as argued by former ASEAN Secretary General Severino, the principle of non-interference is not a dogma, and on the other that ASEAN is significantly evolving towards a greater level of institutionalization. Equally, measures that have been introduced in the fields of relief assistance, rehabilitation and reconstruction to combat natural and man made disasters, inspire a certain degree of optimism. 
The overall analysis provides therefore, substance to the basic assumption of this paper that regional institutions are not "static spaces" but adapt themselves to precise systemic changes. ASEAN and the EU behaviour has been in fact, largely reactive to the structural changes of the international security environment. Then, we observe that new competences and capacities have grown under the impetus of external events rather than from coherent and strategic plans. The related consequence is that, as noted by Henry (2007), EU and ASEAN objectives and aims look increasingly alike. This is particularly notable in the new initiatives undertaken under the patronage of the APSC, which mark a fundamental departure from the traditional ASEAN informal mode of cooperation, the principle of non-interference and a realistic notion of security. Additionally, the distance between the EU security model appears reduced by new ASEAN responsibilities in the field of conflict prevention, conflict resolution and post-conflict management, which are designed to expand the role of the Association from a mere confidence builder to a genuine problem solver.

Yet it is far-fetched to believe that the ASEAN and the EU security systems will intersect. Differences, however, should not obscure the fact that the EU and ASEAN approaches to security are appearing to co-evolve in tandem with new directions and sources of insecurity. This may, therefore, suggest that EU and ASEAN security polices in the area of NTS may be driven to convergence in the long term, as both institutions are guided by what See Tang has defined as a "ethical responsibility to protect" (Seng Tang 2011). It has to be seen if these regional institutions will be able to translate their policies into effective achievements.

Acknowledgments I owe special thanks to Professor Fulvio Attinà and Professor Amitav Acharya for their precious guidance and insights on the EU and ASEAN security systems. My gratitude goes also to Carla Monteleone, to the editor and to the anonymous referees for their useful comments and suggestions on an earlier draft of this paper. I finally wish to thank the Institute of Southeast Asian Studies (ISEAS) in Singapore for valuable sources and materials.

\section{References}

Acharya A (2009) Constructing a security community in Southeast Asia. ASEAN and the problem of regional order. Routledge, New York

Acharya A (1999) Culture, security, multilateralism: the "Asean Way" and Regional Order. In: Krause K (ed) Culture and security, multilateralism, arms control and security building. Frank Cass, London

Åhman T, Nilson C (2009) The community mechanism for civil protection and the European Union solidarity fund. In: Olsson S (ed) Crisis management in the European Union. Springer, Heidelberg

Amer R (2008) The Asian peace. What is the role for the Association of Southeast Asian Nations (ASEAN)? Paper prepared panel SD19 on Just and Durable Peace, International Studies Association, 49th Annual Convention, San Francisco

Banerjee D (1999) Towards comprehensive and cooperative security in South Asia. South Asian Survey 6 (2):305-318

Banlaloi RC (2009) Counter Terrorism Measures in Southeast Asia-How effective are they? De La Salle University, Yuchengco Center, Manila

Beck U (2002) The terrorist threat: world risk society revisited. Theory, Culture Society, 19, 4, pp 39-45.

Beyer C (2008) The European Union as a security policy actor: the case of counterterrorism. European Foreign Affairs Review 13:293-325

Bindi F (2010) The European Union foreign policy: A historical overview. In: Bindi F (ed) The European Union foreign policy: A historical overview. Brookings Institution Press, Washington 
Biscop S (2005) The European security strategy. A global agenda for positive power. Aldershot: Ashgate, 2005

Biscop S, Coolsaet R (2003) The world is the stage — a global security strategy for the European Union. Notre Europe, policy paper n. 8

Boin A, Ekengren M (2009) Preparing for the world risk society: towards a new European security paradigm for the European Union. Journal of Contingencies and Crises Management 17(4):285-294

Boin A, Rhinard M (2008) Managing transboundary crises: What role for the European Union. Int Stud Rev 10:1-26

Buzan B (1997) Rethinking security after the Cold War. Cooperation and Conflict 32(1):5-28

Caballero Anthony M (2010) Non Traditional Security Challenges, regional Governance and the ASEAN Political Security Community (APSC), Asia Security Initiative Policy Series, WP n. 7.

Caballero Anthony M (2008) Non traditional security and infectious diseases in ASEAN — going beyond the rhetoric of securitization to deeper institutionalization. Pac Rev 21(4):509-527

Caballero Anthony M (1998) Mechanisms of dispute settlement: the ASEAN experience. Contemporary Southeast Asia 20(1):38-66

Caballero Anthony M, Emmers R, Acharya A (2006) Non traditional security in Asia: dilemmas in securitization. Ashgate, London

Duke S, Ojanen H (2006) Bridging internal and external security: lessons from European Security and defence policy. European Integration 28(5):477-494

Ekengren M (2008) From a European Security Community to a Secure European Community, Tracing the New Security Identity of the EU. In: Brauch HG (ed) Globalisation and Environmental Challenges. Reconceptualising security in the 21 century. Springer, Berlin

Ekengren $\mathrm{M}$ et al.. (2006) The new security role of the EU: transnational crisis management and the protection of Union citizens. Acta Series B35.

Emmers R (2009) Comprehensive security and resilience in Southeast Asia: ASEAN's approach to terrorism. Pac Rev 22(2):159-177

Guilloux A (2009) Regional governance and disaster response. In: Thomas N (ed) Governance and regionalism in Asia. Routledge, London

Hay C (1995) Structure and agency. In: Marsh D, Stoker G (eds) Theory and methods in political science. Macmillan Press Ltd., Basingstoke

Henry L (2007) The ASEAN way and community integration: two different models of regionalism. European Law Journal 13(6):857-879

Jetschke A, Murray P (2011) Diffusing regional integration: the EU and Southeast Asia. West European Politics 35(1):174-191

Katzenstein P (2005) A world of regions. Asia and Europe in the American imperium. Cornell University Press, Ithaca

Kirchner E, Sperling J (2007) EU security governance. Manchester University Press, Manchester

Maier-Knapp, N (2010) A friend in need. A friend in deed? ASEAN-EU Interregionalism in the light of non-traditional security crises in South-East Asia. Current Research on Southeast Asia, 3, 1, pp 76-100.

Manners I (2002) Normative power Europe: a contradiction in terms? Journal of Common Market Studies $40(2): 235-58$

Monar J (2007) Common threats and common responses. The European Union's counter-terrorism. Strategy and its problems. Gov Oppos 42(3):292-313

Moschini R (2008) The comprehensive security concept of the european union, in globalisation and environmental challenges, in Brauch HG et al.. (eds) Globalisation and environmental challenges. Reconceptualising security in the 21 century. Berlin: Springer.

Murray P, Rees N (2010) European and Asian regionalism: forms and functions. International Politics 47(3/4):269-275

Narine S (2008) Forty years of ASEAN: a historical review. Pac Rev 21(4):411-429

Rees N (2010) EU and ASEAN, issues of regional security. International Politics 47(3-4):402-418

Seng Tang S (2011) Providers not protectors: institutionalizing responsible sovereignty in Southeast Asia. Asian Security 7(1):201-217

Singh D, Acharya A (2009) Regional responses to terrorism in Southeast Asia. In: Singh D (ed) Terrorism in South and Southeast Asian in the coming decade. Singapore, Institute of Southeast Asian Studies

Sukma R (2010) ASEAN and non traditional Security, Tokyo, 3 December.

Vaughn B et al. (2009) Terrorism in Southeast Asia. Congressional Research Service, CRS Report for Congress, 16 October. 


\section{Selected Official Documents}

Secretariat ASEAN (2009) ASEAN Political Security Blueprint. ASEAN Secretariat, Jakarta

ASEAN Secretariat (2007) The ASEAN Charter, Jakarta. Available on ASEAN website http://www.aseanse c.org/publications/ASEAN-Charter.pdf.

ASEAN Secretariat (2007) ASEAN Convention on Counterterrorism, Cebu, 13 January. Available on

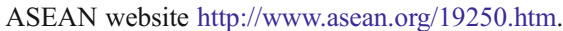

ASEAN Secretariat (2005) Declaration on Action to Strengthen Emergency, Relief, Rehabilitation and Reconstruction, Special ASEAN Leaders Meeting on the aftermath of Earthquake and Tsunami, Jakarta, 6 January. Available at ASEAN website: http://www.asean.org/17066.htm

ASEAN Secretariat (2005) ASEAN Agreement on Disaster Management and Emergency Response, Vientiane, 26 July. Available at ASEAN website http://www.asean.org/17579.htm.

ASEAN Secretariat (2003) Declaration of ASEAN Concord II, Bali, Indonesia, 7 October. Available on ASEAN website http://www.aseansec.org/15159.htm.

ASEAN Secretariat (2002) Declaration on Terrorism by the Eight ASEAN Summit, Phnom Penh, 3 November. Available at ASEAN website http://www.aseansec.org/13154.htm.

ASEAN Secretariat, The ASEAN Regional Programme on Disaster Management. Available at ASEAN website: http://www.asean.org/18455.htm.

ASEAN Secretariat (1976) ASEAN Declaration on Mutual Assistance on Natural Disasters, Manila, 26 June. Available at ASEAN website: http://www.asean.org/17455.htm.

Cologne European Council (1999) 3 and 4 June.

Council of the European Union (2003) A Secure Europe in a Better World. European Security Strategy, Brussels

Council of the EU (2010), Draft internal security strategy for the European Union: towards a European Security Model, Brussels, 23 February.

European Council (1999), 10 and 11 December.

Joint Declaration issued at the British-France Summit (1998), Saint Malo, 4 December.

Report on the Implementation of the European Security Strategy — Providing Security in Changing World (2008), Brussels, 11 December. 